\title{
HASIL BELAJAR MATEMATIKA DITINJAU DARI MODEL PEMBELAJARAN TEAMS ASSISTED INDIVIDUALIZATION (TAI)
}

\author{
MAMAN ACHDIYAT \\ FITRIYA ANDRIYANI \\ Program Studi Pendidikan Matematika \\ Fakultas Teknik Matematika dan IPA Universitas Indraprasta PGRI \\ mamanachdiyat9@gmail.com
}

\begin{abstract}
Abstrak.Tujuan dari penelitian ini adalah untuk mengetahui pengaruh penggunaan model pembelajaran Teams Assisted Individualization (TAI) terhadap hasil belajar matematika siswa pada materi barisan dan deret tak hingga di kelas XI. Metode yang digunakan adalah eksperimen dengan menganalisis perbedaan hasil belajar matematika siswa pada materi barisan dan deret tak hingga antara kelas yang diajar menggunakan model pembelajaran Teams Assisted Individualization dengan kelas yang diajar menggunakan metode ekspositori. Dari data yang terkumpul diperoleh bahwa hasil belajar matematika siswa yang diajarkan dengan model pembelajaran TAI lebih tinggi dibandingkan hasil belajar siswa yang diajarkan dengan ekspositori Setelah hipotesis diuji t, maka diperoleh $\mathrm{t}_{\text {hitung }}=4,48$ dan $\mathrm{t}_{\text {tabel }}=1,684$ pada taraf signifikan 0,05. Dengan demikian, maka $\mathrm{t}_{\text {hitung }}>$ $t_{\text {tabel}}$, sehingga hal ini membuktikan bahwa hasil belajar matematika siswa yang diajar dengan TAI lebih tinggi dibandingkan hasil belajar siswa yang diajar dengan ekspositori.
\end{abstract}

\section{Kata kunci: Hasil Belajar Matematika, Model Pembelajaran Teams Assisted Individualization}

\section{PENDAHULUAN}

Pendidikan merupakan proses pengembangan dan daya nalar, keterampilan dan moralitas kehidupan pada potensi yang dimiliki oleh setiap manusia. Pendidikan juga sangat penting dalam menentukan kemajuan suatu bangsa, terutama bagi negara-negara berkembang seperti Indonesia. Agar dapat mewujudkan keberhasilan dalam pendidikan maka diperlukan suatu sistem pendidikan yang terstruktur dengan baik, sumber daya manusia (SDM) yang handal, serta sarana dan prasarana yang mendukung. Dalam undang-undang Republik Indonesia No. 20 tahun 2003 pasal 1 tentang sistem pendidikan nasional, menerangkan bahwa yang dimaksud dengan:

"Pendidikan adalah usaha sadar dan terencana untuk mewujudkan suasana belajar dan proses pembelajaran agar peserta didik secara aktif mengembangkan potensi dirinya untuk memiliki kekuatan spiritual keagamaan, pengendalian diri, kepribadian, kecerdasan, akhlak mulia, serta keterampilan yang diperlukan dirinya, masyarakat, bangsa dan negara".

Dari definisi di atas dapat disimpulkan bahwa untuk mencapai keberhasilan suatu pendidikan maka dibutuhkan kesadaran dari peserta didik untuk mau belajar kemudian didukung oleh tenaga pengajar yang kompeten sehingga dapat tercipta suasana belajar yang kondusif. Apabila suasana belajar kondusif maka keberhasilan proses belajar mengajar akan dapat tercapai sehingga potensi yang ada pada peserta didik dapat dikembangkan. Dengan demikian maka peserta didik akan memiliki kemampuan, pengendalian diri, kepribadian yang baik, kecerdasan, perilaku serta keterampilan yang diperlukan dirinya, masyarakat, bangsa, dan negara.

Proses pendidikan tidak terlepas dari kegiatan belajar mengajar di kelas. Kegiatan belajar mengajar sangat ditentukan oleh kerjasama antara guru dan siswa. Guru dituntut 
untuk mampu menyajikan materi pelajaran dengan optimal. Oleh karena itu diperlukan kreativitas dan gagasan yang baru untuk mengembangkan cara penyajian materi pelajaran di sekolah. Kreativitas yang dimaksud adalah kemampuan seorang guru dalam memilih metode pendekatan, dan media yang tepat dalam penyajian materi pelajaran.

Di Indonesia pendidikan saat ini merupakan bagian yang sangat penting dan membutuhkan perhatian yang lebih intensif dari banyak pihak. Hal ini dikarenakan fungsi dan tujuan pendidikan nasional yang tercantum dalam UU No. 20 tahun 2003 bab II pasal 3 bahwa: "Pendidikan Nasional berfungsi untuk mengembangkan kemampuan dan membentuk watak serta peradaban bangsa yang bermartabat dalam rangka mencerdaskan kehidupan bangsa, bertujuan untuk mengembangkan potensi agar menjadi manusia yang beriman dan bertakwa kepada Tuhan Yang Maha Esa, berakhlak mulia, sehat, berilmu, cakap, kreatif, mandiri, dan menjadi warga negara yang demokratis serta bertanggung jawab". Oleh karena itu, pendidikan perlu dilaksanakan terpadu, serasi dan teratur serta pelaksanaan pendidikan didukung oleh partisipasi aktif pemerintah, berbagai kelompok masyarakat, pihak orang tua dan dewan kependidikan.

Dalam proses belajar mengajar terkadang terjadi persepsi yang negatif, karena dalam penyampaian informasi suatu ilmu, guru terkadang kurang melakukan proses pembentukan konsep sehingga siswa belum mencapai belajar yang bermakna. Siswa lebih terfokus dari apa yang mereka lihat dan mereka dengar dalam proses belajar mengajar daripada mengalami belajar itu sendiri.

Dengan mengingat adanya perbedaan taraf berfikir pada setiap peserta didik, dan adanya kesulitan yang dimiliki peserta didik dalam memecahkan masalah pada pembelajaran matematika, maka dengan keterampilan dan keahlian yang dimiliki seorang guru diharapkan mampu memilih model pembelajaran yang tepat agar peserta didik mampu menguasai pelajaran sesuai dengan target yang akan dicapai dalam kurikulum. Selain itu perlu adanya perubahan dan pembaharuan pada model pembelajaran yang tradisional menjadi model pembelajaran yang lebih berkualitas.

Tercapainya sebuah tujuan belajar tidak hanya tergantung pada kemampuan guru dalam menciptakan kegiatan pembelajaran, yang akhirnya akan mampu mendorong aktivitas siswa dalam proses kegiatan belajar mengajar. Salah satu unsur lain adalah pemilihan dan penggunaan metode belajar yang tepat dan sesuai dengan kebutuhan belajar. Aktivitas pembelajaran kooperatif menekankan pada kesadaran peserta didik perlu belajar berfikir, memecahkan masalah dan belajar untuk mengaplikasikan pengetahuannya kepada anggota lain dalam kelompoknya. Peserta didik yang membutuhkan dan merasa senang menyumbangkan pengetahuannya kepada anggota lain dalam kelompoknya dan saling membantu juga bekerjasama satu sama lain.

Dengan dasar asumsi di atas, maka penelitian mencoba untuk melakukan sebuah penelitian terhadap salah satu model pembelajaran kooperatif tipe Teams Assisted Individualization (TAI). Model pembelajaran kooperatif tipe TAI, peserta didiknya ditempatkan dalam kelompok-kelompok kecil yang heterogen dan selanjutnya diikuti dengan pemberian bantuan secara individu bagi peserta didik yang memerlukannya. Metode pembelajaran ini perlu diteliti untuk mencari metode pembelajaran alternatif yang tepat dan mengacu pada pengembangan metode-metode pembelajaran yang dapat mengaktifkan peserta didik dan melibatkan guru secara langsung sebagai mitra kerja dalam proses pembelajaran.

Berdasarkan uraian di atas maka perlu dikaji dalam sebuah penelitian, tujuan penelitian ini untuk mengetahui metode yang efektif dan efisien dalam pengajaran. Sehingga peneliti tertarik untuk melakukan penelitian dengan judul "Pengaruh Model Pembelajaran Teams Assisted Individualization (TAI) Terhadap Hasil Belajar Matematika". 


\section{TINJAUAN PUSTAKA}

\section{Hasil Belajar Matematika}

Hasil belajar adalah perubahan yang terjadi pada individu yang belajar, bukan saja perubahan mengenai pengetahuan tetapi juga pembentukan kecakapan, sikap, pengertian, penguasaan, dan penghargaan dalam diri individu yang belajar. Pembelajaran adalah upaya untuk menciptakan pelayanan terhadap kemampuan, potensi, minat, bakat dan kebutuhan peserta didik yang beragam agar terjadi interaksi optimal antara guru dengan siswa serta antara siswa dengan siswa.

Belajar dilakukan untuk mengusahakan adanya perubahan perilaku pada individu yang belajar. Perubahan perilaku itu merupakan perolehan yang menjadi hasil belajar. Jadi hasil belajar adalah perubahan yang mengakibatkan manusia berubah dalam sikap dan tingkah laku.

Dimyati dan Mudjiono (2006:3), "Hasil belajar merupakan hasil dari suatu tindak belajar dan tindak mengajar". Jika dari sisi guru, tindak mengajar diakhiri dengan proses evaluasi hasil belajar, maka dari siswa, hasil belajar merupakan berakhirnya penggal dan puncak proses mengajar.

Menurut Syariffudin (Djamarah, 2010:37), "Hasil belajar adalah pencapaian prestasi belajar yang dicapai siswa dengan kriteria atau nilai yang telah ditetapkan baik penggunaan penilaian acuan patokan maupun penilaian acuan norma".

Matematika merupakan salah satu mata pelajaran yang diajarkan di sekolah. Menurut Yusuf (2003:1), "Matematika penting sebagai pembentuk sikap, oleh karena itu salah satu tugas guru adalah mendorong siswa agar dapat belajar dengan baik". Dengan demikian matematika merupakan mata pelajaran yang dapat menjadi wahana bagi para siswa untuk berfikir kritis, logis dan kreatif.

Bidang studi matematika merupakan salah satu bidang studi yang memerlukan kemampuan kognitif dari siswa, dimana dalam pelajaran matematika ini siswa dituntut untuk dapat berpikir abstrak karena matematika adalah suatu abstraksi, suatu generalisasi yang harus dipelajari dari konsep-konsep yang telah tumbuh lama dari generasi ke generasi. Selain itu, matematika adalah alat berpikir yang mendasari semua ilmu dalam kehidupan manusia. Pada hakikatnya pengajaran yang ditanamkan matematika adalah untuk memperbaiki dan mengembangkan daya mental anak didik, atau siapapun yang terlibat di dalam proses belajar matematika.

Hasil belajar merupakan masalah yang sangat penting bagi siswa maupun bagi pendidik. Hasil belajar yang baik adalah keinginan yang dicita-citakan oleh setiap siswa maupun pendidik. Apabila hasil belajar siswa baik, maka dapat dikatakan proses pengajaran oleh pendidik berhasil baik, tetapi jika hasil belajar yang dicapai siswa rendah, maka dapat dikatakan bahwa pengajaran yang dilakukan oleh guru belum berhasil dengan baik. Guru sebagai pengajar mempunyai tanggung jawab yang besar dalam proses kegiatan belajar siswa, hal ini berarti bahwa setiap guru harus mengetahui hasil belajar siswa.

Berdasarkan beberapa definisi tersebut dapat disimpulkan bahwa hasil belajar matematika adalah hasil dari seseorang siswa dalam mengikuti proses pengajaran matematika pada jenjang pendidikan yang diukur dari kemampuan siswa tersebut dalam menyelesaikan suatu permasalahan matematika dan dilihat dengan skor hasil belajar matematika siswa setelah melalui pemberian tes sebagai alat ukur hasil belajar matematika.

\section{Model Pembelajaran Teams Assisted Individualization (TAI)}

Pada hakikatnya kata "Model" memiliki definisi yang berbeda-beda sesuai dengan bidang ilmu atau pengetahuan yang mengadopsinya.Dalam Kamus Besar Bahasa 
Indonesia(2008: 923), "Model adalah pola (contoh, acuan, ragam, dan sebagainya) dari sesuatu yang akan dibuat atau dihasilkan". Begitupun dengan istilah model pembelajaran tidak akan terlepas dari pola. Contoh, acuan yang dapat dijadikan pedoman dalam melaksanakan pembelajaran.

Suatu pembelajaran dikatakan baik apabila proses pembelajarannya berlangsung efektif sekaligus menggunakan metode yang sesuai dengan materi yang diajarkan, yang pada akhirnya membuahkan hasil sesuai yang diharapkan. Dalam mencapai suatu tujuan pembelajaran, guru mempunyai peranan yang sangat penting. Guru tidak hanya dituntut menguasai materi pelajaran, tetapi juga diharapkan mampu mengupayakan berbagai cara atau metode mengajar yang dapat menunjang tercapainya tujuan pembelajaran yang telah ditetapkan.

Metode secara harfiah berarti cara. Dalam pemakaian yangumum, metode diartikan sebagai suatu cara atau prosedur yang dipakai untuk mencapai tujuan tertentu. Metode pembelajaran berarti cara-cara yang dipakai untuk menyajikan bahan pelajaran kepada peserta didik untuk mencapai tujuan pembelajaran yang telah ditentukan. Salah satu keterampilan guru yang memegang posisi penting adalah keterampilan memilih metode pembelajaran.

Metode merupakan alat untuk mencapai tujuan pembelajaran tertentu dan memiliki peranan yang sangat strategi. Nilai strategis metode pembelajaran adalah dapat mempengaruhi jalannya kegiatan pembelajaran. Suatu contoh kegiatan pembelajaran yang dilakukan guru menjadi kurang terjadi interaksi antara guru dan peserta didik serta kurang memberikan motivasi belajar kepada peserta didik karena menggunakan metode pembelajaran yang kurang tepat.

Metode mengajar pada umumnya ditujukan untuk membimbing peserta didik dalam belajar sesuai dengan bakat dan kemampuan masing-masing. Menurut Undangundang RI No. 20 tahun 2003 tentang pendidikan Nasional, "Pembelajaran adalah proses interaksi peserta didik dengan pendidikan dan sumber belajar pada suatu lingkungan belajar." Semua itu saling berkaitan untuk menciptakan suatu hasil belajar yang memuaskan. Syah (2002:93) berpendapat bahwa "Metode pembelajaran adalah cara yang berisi prosedur baku untuk melaksanakan kegiatan kependidikan khususnya kegiatan pengajaran mata pelajaran kepada siswa".

Pembelajaran kooperatif adalah metode pembelajaran dimana siswa bekerja sama dalam kelompok kecil yang saling membantu, kelompok yang dibentuk terdiri dari 4 siswa yang memiliki kemampuan yang berbeda-beda (Huda,2011:32). Sedangkan metode pembelajaran kooperatif tipe TAI (Team Assisted Individulaization) adalah salah satu tipe metode pembelajaran kooperatif yang menekankan pada kemampuan individu, dimana individu-individu tersebut memiliki kemampuan yang berbeda-beda dan dijadikan dalam suatu kelompok kecil. Dalam kelompok kecil ini yang terdiri dari 4-5 orang dan dengan kemampuan yang heterogen tersebut, diharapkan antar individu dapat saling bekerjasama untuk mencapai tujuan pembelajaran. Metode pembelajaran kooperatif tipe TAI adalah suatu metode pembelajaran yang pertama kali diprakarsai oleh Robert E. Slavin yang merupakan perpaduan antara pembelajaran kooperatif dan pengajaran individual "Team Assisted Individualization" dapat diterjemahkan sebagai kelompok yang dibantu secara individual atau kelompok dimana ada seorang asisten yang membantu secara individual. Selama pelaksanaan TAI guru tidak banyak menjelaskan materi kepada siswa, guru hanya menyiapkan garis besar materi dalam bentuk pertanyaan yang akan menjadi petunjuk diskusi kelompok agar diskusi dapat terfokus. Di samping itu guru hanya sebagai fasilitator dan mediator dalam kegiatan belajar mengajar.

Menurut Sharan (2009:20 dalam Nugroho), "Teams Assisted Individualization (TAI) dikembangkan untuk beberapa alasan. Pertama, berharap agar Teams Assisted 
Individualization (TAI) menyediakan cara penggabungan kekuatan motivasi dan bantuan teman sekelas pada pembelajaran kooperatif dengan program pengajaran individual yang mampu memberi semua peserta didik materi yang sesuai dengan tingkat kemampuan mereka dalam bidang matematika dan memungkinkan mereka untuk memulai materimateri ini berdasarkan kemampuan mereka sendiri. Kedua, mengembangkan Teams Assisted Individualization (TAI) untuk menerapkan teknik pembelajaran kooperatif untuk memecahkan banyak masalah pengajaran individual.

Pada pembelajaran kooperatif tipe Teams Assisted Individualization (TAI), siswa saling membantu dan saling memiliki ketergantungan secara positif, dan akhirnya membentuk sikap gotong-royong dalam mencapai tujuan pembelajaran dan kemandirian belajar. Dengan demikian, alternatif yang diterapkan ini merupakan pilihan yang paling banyak memberikan keuntungan (Murtadlo, 2005:54). Dengan diterapkannya pembelajaran kooperatif tipe Teams Assisted Individualization (TAI) beserta pengembangan perangkat penilaiannya maka diharapkan tujuan pembelajaran yang telah direncanakan dapat tercapai (Irianto dan Ahmad, 2012:3).

Dalam metode Teams Assisted Individualization (TAI) peran pendidik hanya sebagai fasilitator dan mediator dalam proses belajar mengajar. Pendidik cukup menciptakan kondisi lingkungan belajar yang kondusif bagi peserta didiknya. Pengajaran Teams Assisted Individualization (TAI) memotivasi siswa untuk membantu anggota kelompoknya sehingga terciptanya semangat dalam sistem kompetensi dengan sedikit menonjolkan peran individu tanpa mengorbankan aspek kooperatif (Slavin, 2008:195 Penerjemah Nurulita Yusron).

Tahapan pembelajaran kooperatif TAI, yakni: 1) Guru memberikan tugas kepada siswa untuk mempelajarimateri pembelajaran secara individual yang sudah disiapkan oleh guru, 2) Guru memberikan kuis secara individu kepada siswa untuk mendapatkan skor dasar atau skor awal, 3) Guru membentuk beberapa kelompok, setiap kelompok terdiri dari 4-5 siswa dengan kemampuan yang berbeda-beda baik tingkat kemampuan (tinggi, sedang, rendah). Jika mungkin anggota kelompok berasal dari ras, suku, budaya yang berbeda serta kesetaraan gender, 4) Hasil belajar siswa individual didiskusikan dalam kelompok. Dalam diskusi kelompok, setiap anggota saling memeriksa jawaban teman 1 kelompok, 5) Guru memfasilitasi siswa dalam membuat rangkuman, mengarahkan, dan memberikan penegasan pada materi pembelajaran yang telah dipelajari, 6) Guru memberikan kuis kepada siswa secara individu, dan 7) Guru memberikan penghargaan kepada kelompok berdasarkan perolehan nilai peningkatan hasil belajar individual dari skor dasar ke skor kuis berikutnya (terkini).

\section{Hakikat Model Pembelajaran Ekspositori}

Metode ekspositori adalah metode pembelajaran yang digunakan dengan memberikan keterangan terlebih dahulu definisi, prinsip dan konsep materi pelajaran serta memberikan contoh-contoh latihan pemecahan masalah dalam bentuk ceramah, demonstrasi, tanya jawab dan penugasan. Siswa mengikuti pola yang ditetapkan oleh guru secara cermat. Penggunaan metode ekspositori merupakan metode pembelajaran mengarah kepada tersampaikannya isi pelajaran kepada siswa secara langsung.

Menurut Sanjaya (2008:176), "Metode ekspositori adalah pembelajaran yang menekankan kepada proses penyampaian materi secara verbal dari seorang guru kepada sekelompok siswa dengan maksud agar siswa dapat menguasai materi secara optimal". Dengan demikian metode ekspositori adalah metode ceramah yang digunakan guru kepada siswa agar siswa dapat mengerti dan memahami materi yang diberikan oleh guru.

Dari beberapa pendapat di atas, metode ekspositori merupakan bentuk dari pendekatan pembelajaran yang berorientasi kepada guru (teacher centered approach). 
Dikatakan demikian sebab guru memegang peran sangat dominan. Melalui metode ini guru menyampaikan materi pembelajaran secara terstruktur dengan harapan materi pelajaran yang disampaikan itu dapat dikuasai siswa dengan baik. Metode ekspositori yang digunakan dalam penelitian ini adalah mengkombinasikan metode ceramah, tanya jawab dan pemberian tugas.

Menurut Sanjaya (2008:177) Langkah-langkah dalam metode ekspositori adalah sebagai berikut: 1) Persiapan (preparation), mempersiapkan siswa untuk menerima pelajaran, 2) Penyajian (presentation), menyampaikan materi pelajaran sesuai dengan persiapan yang telah dilakukan, 3) Korelasi (correlation), memberikan makna terhadap materi pelajaran, baik makna untuk memperbaiki struktur pengetahuan yang telah dimiliki siswa, 4) Menyimpulkan (generalization), menyimpulkan adalah memahami inti dari materi pelajaran yang telah disajikan, dan 5) Mengaplikasikan (aplication), untuk kemampuan siswa setelah mereka menyimak penjelasan guru.

Dari beberapa pendapat di atas langkah-langkah metode ekspositori adalah mempersiapkan, menyusun, menyajikan, menyampaikan, menyimpulkan, mengevaluasi, materi yang akan disampaikan kepada siswa, sehingga siswa dapat mengerti dengan jelas tentang materi yang diberikan oleh guru.

Dari beberapa pendapat di atas kelebihan metode ekspositori adalah strategi pembelajaran yang menekankan kepada proses penyampaian materi secara verbal dari seorang guru kepada siswa dengan maksud agar siswa dapat menguasai materi pelajaran yang disampaikan secara optimal.

\section{METODE}

Metode yang digunakan dalam penelitian ini adalah metode eksperimen semu (quasi eksperimen). Eksperimen semu adalah eksperimen yang belum atau tidak memiliki ciri-ciri rancangan eksperimen yang sebenarnya, karena variabel-variabel yang harusnya dikontrol atau dimanipulasi. Oleh karena itu, validitas penelitian menjadi kurang cukup untuk disebut sebagai eksperimen yang sebenarnya. Metode eksperimen pada penelitian ini bertujuan untuk mengetahui perbandingan dua kelompok yang diberi perlakuan berbeda yaitu kelompok pengajaran yang menggunakan metode TAI dan metode ekspositori.

Adapun Desain Penelitian adalah sebagai berikut:

Tabel 1. Desain Penelitian

\begin{tabular}{|c|c|}
\hline $\mathrm{X}_{11}$ & $\mathrm{X}_{12}$ \\
\hline $\mathrm{Y}_{11}$ & $\mathrm{Y}_{12}$ \\
\hline
\end{tabular}

Keterangan:

$\mathrm{X}_{11}$

: Kelas Eksperimen (Metode TAI)

$\mathrm{X}_{12}$

: Kelas Kontrol (Metode Ekspositori)

$\mathrm{Y}_{11}$

: Hasil Belajar Matematika kelas Eksperimen

$\mathrm{Y}_{12}$

: Hasil Belajar Matematika kelas Kontrol

Populasi target dalam penelitian ini adalah siswa kelas XI SMAN 4 Tangerang. Sedangkan Populasi terjangkaunya adalah Seluruh siswa kelas XI SMA Negeri 4 Tangerang tahun ajaran 2014/2015 sebanyak 353 siswa. Sampel penelitian ini adalah diambil dari populasi terjangkau sebanyak 40 siswa yang terdiri 20 siswa kelas XI-IPS.3 (kelas eksperimen) dan 20 siswa dari kelas XI-IPS.4 (kelas kontrol). Adapun teknik pengambilan sampel yang digunakan adalah dengan menggunakan simple random sampling. "Simple random sampling adalah teknik pengambilan sampel yang dilakukan 
secara acak sehingga setiap kasus dalam populasi memiliki kesempatan yang besar untuk dipilih sebagai sampel penelitian." (Subiyanto, 2009)

\section{HASIL DAN PEMBAHASAN}

\section{Deskripsi Data}

\section{Hasil Belajar Matematika Kelas Eksperimen}

Berdasarkan data hasil belajar matematika siswa pokok bahasan barisan dan deret tak hingga kelas eksperimen diperoleh nilai antara 54-98 dengan nilai rata-rata 76,9 sedangkan nilai modus 76, nilai median 76,5 dan nilai simpangan baku 10,49. Dari data di atas dapat disimpulkan bahwa nilai kemampuan awal matematika siswa tergolong pada kategori cukup, dimana cukup banyak siswa yang mendapatkan nilai di atas rata-rata sehingga dapat disimpulkan bahwa kemampuan awal siswa di SMAN 4 Tangerang tergolong tinggi.

\section{Hasil Belajar Matematika Kelas Kontrol}

Berdasarkan data hasil belajar matematika siswa pokok bahasan barisan dan deret tak hingga kelas kontrol diperoleh nilai antara 53-82 dengan nilai rata-rata 64,20 sedangkan nilai modus 61,9nilai median 62,1 dan nilai simpangan baku 7,15. Dari data di atas dapat disimpulkan bahwa nilai kemampuan awal matematika siswa tergolong pada kategori kurang, dimana banyak siswa yang mendapatkan nilai di bawah rata-rata, sehingga dapat disimpulkan bahwa kemampuan awal siswa di SMAN 4 Tangerang tergolong rendah.

Dari data di atas dapat disimpulkan bahwa hasil belajar matematika pada kelas eksperimen pada siswa kelas XI-IPS.3 SMA Negeri 4 Tangerang lebih baik dari pada kelas kontrol pada siswa kelas XI-IPS.4 SMA Negeri 4 Tangerang.

\section{Uji Normalitas Kelas Eksperimen}

Dari hasil pengujian untuk kelompok eksperimen diperoleh nilai $\chi^{2}{ }_{\text {hitung }}=2,39$ dan dari tabel nilai kritis uji chi kuadrat diperoleh nilai $\chi^{2}$ tabel untuk $\mathrm{n}=20$ pada taraf signifikan $\alpha=0,05$ adalah 7,82 . Karena $\chi^{2}$ hitung kurang dari $\chi^{2}$ tabel $(2,39<5,991)$ maka $\mathrm{H}_{0}$ diterima, artinya data yang terdapat pada kelas eksperimen berasal dari populasi yang berdistribusi normal.

\section{Uji Normalitas Kelas Kontrol}

Uji Normalitas yang digunakan adalah uji chi kuadrat. Dari hasil pengujian untuk kelompok kontrol diperoleh nilai $\chi^{2}$ hitung $=4,28$ dan dari tabel nilai kritis uji chi kuadrat diperoleh nilai $\chi^{2}$ tabel untuk $\mathrm{n}=20$ pada taraf signifikan $\alpha=0,05$ adalah 5,991. Karena

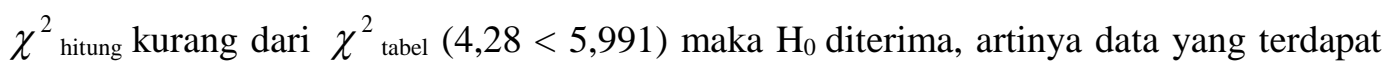
pada kelas kontrol berasal dari populasi yang berdistribusi normal.Untuk lebih jelasnya hasil dari uji normalitas antara kelas eksperimen dan kelas kontrol adalah sebagai berikut berikut:

Karena $\chi^{2}$ hitung pada kedua kelas kurang dari $\chi^{2}$ tabel maka dapat disimpulkan bahwa data populasi kedua kelompok berdistribusi normal.

\section{Uji Homogenitas}

Dari hasil perhitungan diperoleh nilai $\mathrm{F}$ hitung $=2,15$ dan $\mathrm{F}$ tabel $=2,17$ pada taraf signifikansi $\alpha=0,05$ dengan derajat kebebasan pembilang 19 dan derajat kebebasan 


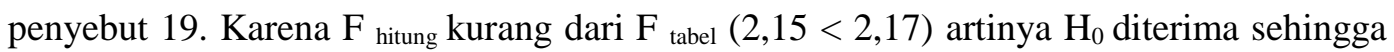
dapat disimpulkan bahwa kedua data memiliki varians yang homogen. Untuk lebih jelasnya hasil dari uji homogenitas dapat dilihat pada tabel berikut:

\section{Pengujian Hipotesis Penelitian}

Setelah uji persyaratan di atas didapat dua kelompok berdistribusi normal dan homogen, dilanjutkan pengujian hipotesis.

$\mathrm{H}_{0}: \mu_{1} \leq \mu_{2}$

$\mathrm{H}_{1:} \mu_{1}>\mu_{2}$

Keterangan:

$\mu_{1}$ : Rata-rata hasil belajar matematika kelompok eksperimen

$\mu_{2}$ : Rata-rata hasil belajar matematika kelompok kontrol

Tipe pengujian yang digunakan adalah pengujian satu pihak, dengan $\alpha=0,05 \mathrm{dan} \mathrm{dk}$ $=\mathrm{n}_{1}+\mathrm{n}_{2}-2$. Jadi $\mathrm{dk}=20+20-2$, dari tabel distribusi $\mathrm{t}$ didapat harga $\mathrm{t}_{0,95}(38)=1,684$. Tolak $\mathrm{H}_{0}$ jika $t_{\text {hitung }}>\mathrm{t}_{\text {tabel }}$ dan terima untuk kriteria lainnya. Kriteria $t_{\text {hitung }}>t_{\text {tabel }}(4,48>$ 1,684) maka $\mathrm{H}_{0}$ ditolak dan $\mathrm{H}_{1}$ diterima pada $\alpha=0,05$. Dengan demikian rata-rata hasil belajar matematika kelompok siswa yang diberi metode TAI lebih tinggi secara signifikan dari rata-rata hasil belajar matematika kelompok siswa yang diberi metode pembelajaran ekspositori atau dengan kata lain pemberian metode TAI mempunyai pengaruh dalam meningkatkan hasil belajar matematika siswa SMAN 4 Tangerang.

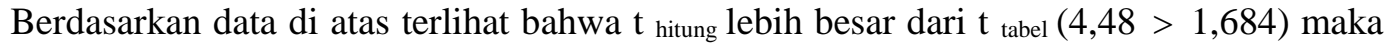
dapat disimpulkan bahwa $\mathrm{H}_{0}$ ditolak dan $\mathrm{H}_{1}$ diterima dengan taraf signifikansi $5 \%$.

\section{Pembahasan}

Berdasarkan hasil penelitian ini terdapat perbedaan rata-rata hasil belajar matematika antara kelompok peserta didik menggunakan metode teams assisted individualization (TAI) dengan kelompok peserta didik menggunakan metode ekspositori. Bisa dikatakan bahwa rata-rata hasil belajar matematika menggunakan metode teams assisted individualization (TAI) lebih tinggi dari pada menggunakan metode ekspositori.

Hal ini disebabkan karena dengan menerapkan metode teams assisted individualization (TAI), maka peserta didik lebih aktif dalam mengerjakan soal yang diberikan guru dan hasil evaluasi belajar peserta didik mengalami peningkatan, karena dengan metode teams assisted individualization (TAI) dapat mengembangkan kemampuan motorik yang sebelumnya dilakukan diagnosis agar kegiatan itu bermanfaat bagi pengembangan motorik peserta didik.

Sedangkan dilain pihak metode ekspositori umumnya dikuasai oleh guru sehingga peserta didik kurang berinteraksi, peserta didik juga terlihat kurang aktif dalam menangkap pelajaran yang diberikan guru sehingga ada kecenderungan untuk melepaskan diri dari tanggung jawab, dalam metode ekspositori ini peserta didik hanya mendengarkan dan memperhatikan apa yang disampaikan oleh guru saja.

\section{PENUTUP}

\section{Simpulan}

Berdasarkan hasil penelitian dan pengajuan hipotesis maka dapat disimpulkan bahwa terdapat pengaruh metode teams assisted individualization (TAI) terhadap hasil belajar matematika dalam penyelesaian materi barisan dan deret tak hingga pada siswa kelas XI SMA Negeri 4 Tangerang tahun pelajaran 2014/2015 semester ganjil. Maka dapat ditarik kesimpulan bahwa hasil belajar matematika yang menggunakan metode teams assisted individualization (TAI) lebih tinggi dibandingkan menggunakan metode ekspositori. 


\section{Saran}

Dari uraian kesimpulan di atas maka penulis mencoba memberikan beberapa saran, sebagai berikut:

1. Keterlibatan Metode pembelajaran sangat diperlukan dalam proses pendidikan, karena akan memberikan power serta motivasi bagi siswa. Siswa yang merasa termotivasi akan dapat meningkatkan hasil belajarnya. Ini berarti dalam proses pembelajaran matematika, hasil belajar matematika dipengaruhi oleh metode pembelajarannya. Penggunaan metode teams assisted individualization (TAI) dalam pembelajaran matematika adalah aktivitas yang menarik bagi siswa jika guru dapat membimbing siswa dalam menempuh langkah-langkah penyelesaian masalah yang dihadapi siswa.

2. Disaran Kepada kepala sekolah yaitu untuk meningkatkan hasil belajar menggunakan metode teams assisted individualization (TAI) yang lebih baik, hendaknya kepala sekolah mengadakan seminar tentang metode teams assisted individualization (TAI) kepada guru matematika dan guru mata pelajaran lain agar para guru dapat mendalami metode teams assisted individualization (TAI) yang sangat efektif pada proses belajar mengajar.

3. Dalam meningkatkan hasil belajar matematika guru matematika SMA Negeri 4 Tangerang lebih baik tetap mempertimbangkan faktor-faktor yang secara teoritis dan empiris mempengaruhi hasil belajar matematika.

4. Disarankan kepada guru pelajaran matematika SMA Negeri 4 Tangerang untuk terus berupaya menggunakan berbagai Metode pembelajaran dalam menjelaskan berbagai materi matematika, sehingga dapat memberikan pengaruh yang lebih besar terhadap hasil belajar matematika pada masa yang akan datang.

5. Disarankan kepada Orang tua memberikan dorongan akan pentingnya belajar matematika. Selain itu orang tua diharapkan dapat berperan aktif dan menunjang kegiatan anak sehari-hari yang ada hubungannya dengan pembelajaran matematika.

\section{DAFTAR PUSTAKA}

Ahmadi, Abu dan Supriyono.2004.Psikologi Belajar. Jakarta: Rineka Cipta.

Arikunto, Suharsimi. 2006. Prosedur Penelitian ( Suatu Pendekatan Praktik). Jakarta: PT Rineke Cipta.

Budi.2010. Manfaat Membumikan Matematika Dari Kampus Ke Kampung. Jakarta: Buku Kita.

Darwati. 2005.Efektifitas Penerapan Modifikasi Perilaku Dalam Meningkatkan Prestasi Belajar Matematika Anak Berkesulitan Belajar Matematika Siswa Kelas 2 Dawung 1 Kec. Matesih. Kab. Karanganyar Tahun Ajaran 2004/2005. SkripsiFKIP UNS.

Depdikbud. 2008. Kamus Besar Bahasa Indonesia. Jakarta: Balai Pustaka.

Depdiknas-Dirjen Dikdasmen. 2003. Undang-Undang RI Tentang system Pendidikan

Nasional. Jakarta: Depdiknas.

Dimyati dan Mudjiono. 2006. Belajar dan Pembelajaran. Jakarta: Rineka Cipta.

Djamarah, Bahri Syahriful. 2010. Strategi Belajar Mengajar. Jakarta: Rineka Cipta.

Erman Suherman. 2003. Strategi Belajar Matematika Kontemporer. Bandung: UPI

Formula Media.

Huda, Miftahul.2011.Cooperative Learning.Yogyakarta: Pustaka Pelajar.

Irianto, Sony dan Ahmad.Pengembangan Perangkat Penilaian Konsep Dasar Matematika SD Berorientasi Pembelajaran Kooperatif Tipe TAI: 1-19. http://jurnal.ump.ac.id/index.php/khasanah/article/download/61/57. 
Murtadlo. 2005. Peningkatan Prestasi Belajar Siswa Berkesulitan Belajar Membaca Menulis Melalui Pendekatan Kooperatif Tipe TAI (Team Assisted Individualization) di SD: Jurnal Pendidikan Dasar, Vol. 6, No.1,2005: 1 -60.

Nugroho, Aryo Andri. Pengembangan Perangkat Pembelajaran Matematika Berbasis SMART dengan Strategi TAI pada Materi Segitiga Kelas VII.http://ejurnal.ikippgrismg.ac.id/index.php/aksioma/article/download/36/32.

Pendidikan. Jakarta: Kencana Prenada Media Group. Rineka Cipta.

Sanjaya, Wina. 2008. Sterategis Pembelajaran Berorientasi Standar Proses

Slameto. 2010. Belajar Dan Faktor - Faktor Yang Mempengaruhinya. Jakarta:

Slavin, R. E. 2008. Cooperative Learning Teori, Riset dan Praktik. Bandung:

Soekresno, Ery dan Rinaldi. 2001. 8 Kiat Anak Mencintai Matematika.Bandung: Asy Syaamil.

Sudjana, Nana.2004. Dasar - dasar Proses Belajar Mengajar. Bandung: Sinar Baru Algensido Off Set.

Sukradinata, Syaodih. 2007. Landasan Psikologi Pendidikan. Bandung: Remaja Rosdakarya.

Suyitno. Model Pembelajaran Teams Assisted Individualization. http://zaifbio.wordpress.com/2013/05/20/model-pembelajaran-tipe-tai-teamassisted-individualization.

Syah, Muhibbin. 2002. Psikologi Pendidikan Dengan Pendekatan Baru. Bandung: Rosdakarya.

Yusuf, M. 2003. Penerapan Model Pembelajaran Kooperatif Tipe Teams Game Tournament Untuk Meningkatkan Prestasi Belajar Matematika. Skripsi Program Studi Pendidikan Matematika Universitas Pendidikan Indonesia. Bandung. Tidak dipublikasikan. 